\title{
Serra da Capivara National Park and the conservation of north-eastern Brazil's caatinga
}

\section{Fábio Olmos}

Serra da Capivara is the second largest protected area in Brazil's caatinga-a mosaic of dry habitats in the north-east with a diverse flora and fauna, including several threatened and recently discovered taxa. The park is not effectively protected, however, and there is growing pressure from the surrounding human population.

Most of north-eastern Brazil is covered by the caatinga, a vast xeric biome characterized by an unpredictable rainfall regime with shifts from extreme drought $(0 \mathrm{~mm}$ of rain/year) to flooding (600 mm of rain in a month) occurring throughout the region (Markhan, 1972; Reis, 1976). This area is the largest dry region in the Neotropics and is bordered by much more mesic habitats (Eiten, 1974).

The vegetation of this semi-arid region is composed of several xeric, deciduous plant assemblages collectively known as caatingas. These range from relatively simple to extremely complex with regard to species abundance, composition, characteristic species and height profiles. A number of different types of vegetation may be found in a relatively small area, creating a vegetational mosaic (Streilein, 1982). Although geographic, edaphic and microclimatic factors are important in shaping these assemblages, the activities of man and domestic animals were a major force in determining the present-day physiognomy of the caatinga. In fact, several authors consider the caatinga to be primarily forest-like, the present-day steppe and bush being the result of human action (Webb, 1974; Sarmiento, 1975).

The caatinga flora shares numerous generic and suprageneric taxa with other plant formations, particularly the chaco, but there is a pronounced level of species endemicity (Andrade-Lima, 1982). Sarmiento (1975) showed that, compared with other arid and semi-arid biomes of South America, the caatinga is the most dissimilar floristically.

There appear to be few endemic vertebrates in the caatinga, but new taxa are still regularly discovered, especially reptiles (Rodrigues, 1984, 1986, 1987, 1988; Manzani and Abe, 1990) and there may be many more awaiting discovery.

Since colonization the caatinga has been transformed, both by extensive cattle-raising

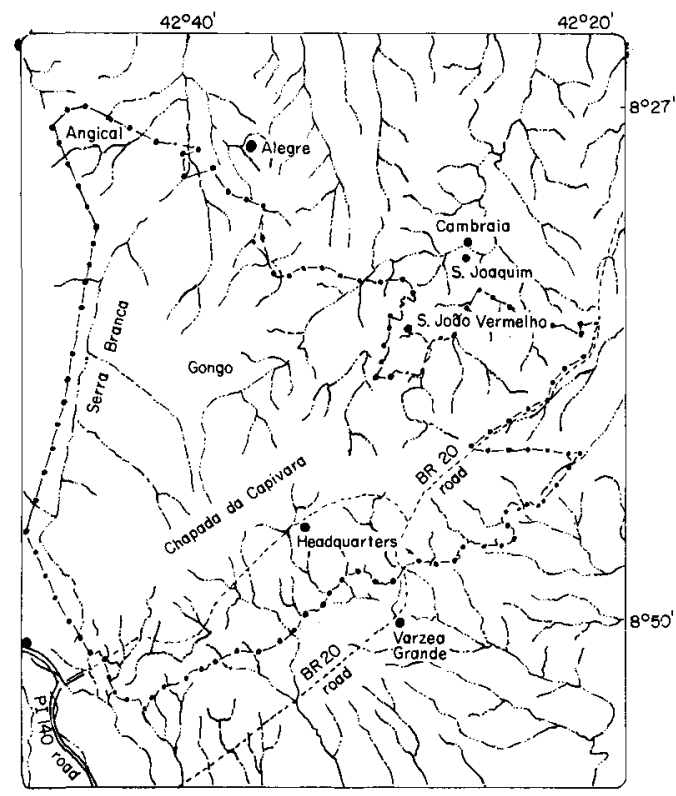

Figure 1. Map of the Serra da Capivara National Park. The heavy dotted line marks the park boundaries. Solid circles denote villages and the park headquarters. All watercourses are temporary. 
and the expansion of agriculture. The exploitation of flora and fauna, frequently boosted by the collapse of other economic activities during droughts, has further damaged habitats, especially the more forested areas, and has caused the local extinction of species of animals used as a source of meat or skins, or as a source of revenue from the pet trade. It is important to emphasize that the north-east is the poorest region of Brazil, a country in severe economic crisis.

The caatinga is the most neglected biome in Brazil from the conservation standpoint. Only 0.1 per cent is protected by four national parks and ecological stations, all of which have serious problems of land tenure, insufficient personnel and area (CIMA, 1991). This paper presents information on the conservation value and status of the second largest of these protected areas, Serra da Capivara National Park.

\section{The park and its flora and fauna}

The Serra da Capivara National Park was created in 1979 mainly to protect the rich archaeological sites of the region, the oldest known in America (Guidon and Delibrias, 1986). It covers 130,000 ha of a sandstone plateau in south-eastern Piaui state (Figure 1).

The plateau is bounded by cliffs $50-200 \mathrm{~m}$ high and dissected by a few deep valleys and canyons. Soils on the plateau are mainly yellow-red latosols, while in the valleys and canyons they are white sand. Along the borders of the plateau there are extensive areas of shallow soil and exposed rock. There is no permanent watercourse in the park, only some springs, water-holes and man-made reservoirs. Most rain falls between September and March, but timing and amount are unpredictable (Emperaire, 1989).

The park's vegetation has been described in detail by Emperaire (1989), who recorded 615 plant species and recognized eight vegetation communities. Five of these are forms of caatinga, ranging from a $15-\mathrm{m}$ tall woodland composed mainly of Anadenanthera macrocarpa and Astronium urundeuva, to a sparse, bushy formation rich in cacti and bromeliads in rocky areas. Most of the park is covered by a species-rich, arboreal-shrubby caatinga (8-10$\mathrm{m}$-tall), which is very difficult to penetrate because of its tangled undergrowth.

In the narrower canyons there are relicts of semi-deciduous forests with trees up to $30 \mathrm{~m}$ tall. The three forest types observed are largely determined by the successional stage of the formation and the microclimatic conditions of the canyon (Emperaire, 1989).

Table 1. Taxa of conservation concern present in Serra da Capivara National Park

\section{Plants}

Astronium urundeuva

Spondias tuberosa

Cordia trichotoma

Bursera leptophloeos

Copaifera langsdorffii

Hymenaea courbaril

Hymenaea stigonocarpa

Senna spectabilis

Anadenanthera macrocarpa

Mimosa verrucosa

Piptadenia obliqua

Amburana cearensis

Dalbergia cearensis

Ziziphus joazeiro

Pilocarpus jaborandi

\section{Mammals}

Jaguar Panthera onca

Puma Felis concolor

Oncilla Felis tigrina

Margay Felis wiedii

Ocelot Felis pardalis

Greater anteater Myrmecophaga tridactyla

Three-banded armadillo Tolypeutes tricinctus

\section{Birds}

Yellow-legged tinamou Crypturellus noctivagus

White-browed guam Penelope jacucaca

Blue-winged macaw Ara maracana

Lesser nightjar Caprimulgus hirundinaceus

Great xenops Megaxenops parnaguae

Silvery-cheeked ant-shrike Sakesphorus cristatus

White-browed ant-wren Herpsilochmus pileatus

White-throated seedeater Sporophila albogularis

Greater thick-billed seedfinch Oryzoborus

maximilianii

Yellow siskin Spinus yarrelli

Sources: FAO (1986), Collar and Andrew (1988), IBAMA (1989). 
Among the plant species found by Emperaire, three proved to be new species: Arrabidaea resinosa, a Jacaranda sp. (both Bignoniaceae) and a Pouteria sp. (Sapotaceae). The last species is one of the most common trees in the canyons. New species are likely to be discovered in the park, especially in the poorly known area between Serra Branca and Gongo (Figure 1).

Most of the plant species in the region are used by local people and about 210 of them have known medicinal properties (Emperaire, 1983), making the park an important area for research on bioactive chemicals.

As well as a large number of caatinga endemics, the park harbours 16 plant taxa considered threatened by the FAO (1986) (Table 1). Most of these still have good populations in the region, making the park very important for their in situ conservation.

Studies on the park's fauna have concentrated on the vertebrate species. Currently the park and its environs are known to harbour 17 species of amphibians, 41 of reptiles, 208 of birds and 57 of mammals (FUMDHAM, 1991). A relict population of a characid fish of the genus Astyanax occurs in the water-filled crevasse formed between the walls of a canyon. This species has yet to be described.

Two other new taxa were recently discovered in the park: an iguanid lizard, Tapinurus helenae (Manzani and Abe, 1990), and a nectarivorous bat of the genus Lonchophylla. More collecting will probably reveal other new taxa.

A total of 10 bird and seven mammal species present in the park are of conservation concern (Table 1). Among these the most important is perhaps the three-banded armadillo, an endangered mammal largely restricted to north-eastern Brazil (Table 1). This armadillo has long been considered rare and has declined probably because it is easy to capture and it has a low reproductive potential (Wetzel, 1982). This species has been found in the western and northern parts of the park, apparently being more common in the former. Nevertheless, population densities are low; hired hunters could find only eight armadillos during 3 months in a similar area near the park.
Other threatened species found in the park occur throughout South America but have vanished from most of north-eastern Brazil. The park's populations of jaguar, great anteater and white-lipped peccary Tayassu pecari may well be the last in the entire caatinga and the only ones to be in a protected area (Table 1). At present there are about six jaguars, even fewer anteaters and about 20 peccaries in three groups.

These populations, together with those of other species, such as brocket deer, collared peccaries, capuchin monkeys, pumas and ocelots, represent ecotypes adapted to the conditions of the caatinga and their conservation is important to safeguard the genetic diversity of these species.

Most species of threatened birds found in the park have secure populations and some are even abundant (F. Olmos, unpubl. data). The species of greater concern are seed-eaters, such as Oryzoborus maximiliani and Spinus yarrelii, which have suffered from trapping and pesticide poisoning when feeding on cultivated pasture, and large birds that have low population densities, such as the scarlet macaw Ara chloroptera and the king vulture Sarcoramphus papa. The seed-eaters could be feasibly reintroduced, as could the recently extinct greater rhea Rhea americana and Spix's macaw Cyanopsitta spixii, which vanished in the early 1970s (N. Guidon, pers. comm.).

\section{Threats to Serra da Capivara National Park}

Despite being created 12 years ago the land tenure of the park has not been settled. About 250 families are still waiting to be indemnified and, although some have abandoned their land, others continue to cultivate and raise cattle in the park.

Cattle-raising is particularly damaging because of the tradition of burning the caatinga to create new browse. The cattle also damage the vegetation of the forested canyons and prevent the recruitment of some species, such as the threatened Astronium urundeuva, as well as competing with native animals for food and 
water during drought periods. Several reservoirs and water-holes are contaminated by cattle faeces and there is the risk of disease being transmitted to wild animals.

These problems are particularly acute around Angical, a 10-family village in the north of the park. A devastating fire, which started near here (reportedly by poachers) burnt the entire Serra Branca valley and its satellite canyons, home of most of the threatened species found in the park, without causing the least concern to the park authorities. Smaller fires have occurred since and are preventing the regeneration of the area.

Poaching is another serious problem in the park. Local people are extremely poor and any wildlife is viewed as a supplement to their diet, including such species as pumas and skunks. There is a strong local tradition in favour of hunting and even wealthier people will spend weekends hunting in the park.

Until the early 1980s commercial hunting of animals for fur and leather was intense, despite the official ban. It ended only after the middleman was seized by federal agents. Although most species appear to have recovered, spotted cats, especially jaguars and ocelots, are still rare. Nevertheless, trade in cage birds and armadillos (eagerly sought for their meat) still continues. It has been reported that full truckloads of armadillos are being sent to neighbouring states. These animals, including the endangered three-banded armadillo, are also commonly found for sale along roads and in the city and village markets.

Poaching is particularly damaging because most species in the caatinga have low population densities and are thus further depleted. During the last 25 years giant armadillos Priodontes maximus, greater rheas and Spix's macaws became extinct due to hunting, while most species of mammals and large birds are now rare.

The problems of hunting and land tenure of the park are consequences of the lack of concern by the Brazilian environmental authorities, specially the federal agency in charge of the national parks and reserves, IBAMA. There is also very little funding available. As of July 1991 the park had no staff and the only protection it received came from a few signboards (quite ineffective in a region where most people are illiterate) and the very occasional patrols that come from the state capital $540 \mathrm{~km}$ north. Because the guards will not travel by foot most of the park is not watched at all. As a result it can be said that Serra da Capivara National Park does not exist as a conservation unit and should be considered to be a park in danger.

On the positive side, a management plan for the park has already been finished by the staff of FUMDHAM, a non-governmental scientific and ecological foundation with 20 years of research experience in the region. The plan envisages more effective protection for the park, through the recruitment of trained personnel and the building of permanent posts at the few points that give access to the park. It also allows for active management and restoration of threatened species and their habitats, and the development of a few archaeological sites as tourist attractions to obtain revenue for the park. Nevertheless, the park must first exist for the plan to be implemented and this will happen only after the Brazilian Government, through IBAMA, regularizes its situation.

\section{References}

Andrade-Lima, D. de. 1982. Present-day forest refuges in northeastern Brazil. In Biological Diversification in the Tropics (ed. G. T. Prance), pp. 245-251. Columbia University Press, NY.

CIMA. 1991. Subsidios tecnicos para a elaboraçao do relatorio nacional do Brasil para a CNUMAD. Brasilia, 172 pp.

Collar, N.J. and Andrew, P. 1988. Birds to Watch: The ICBP World Checklist of Threatened Birds. ICBP Technical Publication 8, Cambridge.

Eiten, G. 1974. An outline of the vegetation of South America. Proc. 5th. Cong. Int. Primat. Soc., Nagoya, Japan. pp. 529-545.

Emperaire, L. 1983. La Caatinga du Sud-est du Piaui (Bresil): Etude Ethnobotanique. Editions Recherche sur les Civilizations, Paris.

Emperaire, L. 1989. Vegetation et Gestion des Resources Naturelles dans la Caatinga du Sud-est du Piaui (Bresil). Editions de l'Orstom TDM 52, Paris.

FAO. 1986. Databook on Endangered Tree and Shrub Species and Provenances. FAO, Rome. 
FUMDHAM. 1991. Plano de manejo do Parque Nacional Serra da Capivara. IBAMA, Brasilia.

Guidon, N. and Delibrias, G. 1986. Carbon 14 dates points to man in the Americas 32,000 years ago. Nature, 132, 769-771.

IBAMA. 1989. Lista oficial das especies da fauna brasileira ameaçada de extinçao. Portaria IBAMA 1522 de 19/9/89. IBAMA, Brasilia.

Markhan, C.G. 1972. Aspectos climatologicos da seca no Brasil-nordeste. Sudene, Recife.

Manzani, P.R. and Abe, A.S. 1990. A new species of Tapinurus from the caatinga of Piaui, northeastern Brazil (Squamata, Tropiduridae). Herpetologica, 46, 462-467.

Reis, A.C. 1976. Clima da caatinga. An. Acad. Brasil. Cienc. 48, 325-335.

Rodrigues, M.T. 1984. Notobachia ablephara, um novo genero e especie do nordeste do Brasil. Papeis Avulsos Zool. S. Paulo, 35, 361-366.

Rodrigues, M.T. 1986. Uma nova especie do genero Phyllopezus de Cabaceiras, Paraiba, Brasil, com comentarios sobre a fauna de lagartos da area. Papeis Avulsos Zool. S. Paulo, 36, 237-250.
Rodrigues, M.T. 1987. Sistematica, ecologia e zoogeografia dos Tropidurus do grupo torquatus ao sul do Amazonas (Sauria, Iguanidae). Arq. Zool. S. Paulo, 31, 105-230.

Rodrigues, M.T. 1988. Tropidurus psamonastes: uma nova especie do grupo torquatus com notas sobre seu cariotipo e distribuiçao. Papeis Avulsos Zool. S. Paulo, 36, 307-313.

Sarmiento, G. 1975. The dry plant formations of South America and their floristic connections. J. Biogeogr. 2, 233-253.

Streilein, K.E. 1982. Th ecology of small mammals in the semi-arid Brazilian Caatinga I: climate and faunal composition. Ann. Carnegie Mus. 51, 79-107.

Webb, K. 1974. The Changing Face of Northeastern Brazil. Columbia University Press, NY.

Wetzel, R. M. 1982. Systematics, distribution, ecology and conservation of South American edentates. Pymatuning Symp. Ecol. 6, 345-375.

Fábio Olmos. r. Antonio F. Gandra 182, S. Vicente, SP, 11390, Brazil. 